\title{
METHODOLOGY FOR AUTOMATICALLY DELIMITING PERMANENT PRESERVATION AREAS ALONG WATER COURSES - THE USE OF GIS IN THE HYDROLOGICAL BASIN OF THE SERGIPE RIVER, BRAZIL ${ }^{1}$
}

\author{
Janisson Batista de Jesus ${ }^{2 *}$ and Bruno Barros de Souza ${ }^{3}$
}

\footnotetext{
${ }^{1}$ Received on 02.09.2014 accepted for publication on 01.12.2015.

${ }^{2}$ Universidade Federal de Sergipe, Programa de Pós-Graduação em Agricultura e Biodiversidade, São Cristóvão, SE - Brasil. E-mail: <janisson-batista-de-jesus@hotmail.com>.

${ }^{3}$ Administração Estadual do Meio Ambiente, Assessoria de Planejamento, Aracaju, SE - Brasil. E-mail: <brunobarros.eco@gmail.com>. ${ }^{*}$ Corresponding author.
}

\begin{abstract}
Permanent Preservation Areas (PPAs) along watercourses have been the focus of numerous studies, not only because of the fragility and ecological relevance of riverine vegetation, but also because of the inefficiency demonstrated in conforming to the legislation protecting it. One of the major difficulties encountered in terms of guaranteeing the effective conservation of these riverside areas is the absence of methodologies that can be used to define them rapidly and accurately without manually determining the widths of the rivers or assigning only uniform linear values for the entire watercourse. The present work sought to develop a spatial analysis methodology capable of automatically defining permanent preservation areas along watercourses using geographic information system (GIS) software. The present study was undertaken in the Sergipe River basin, "considering the river itself and its principal affluents. We used the database of the Digital Atlas of Hydrological Resources (SEMARH/SE), and the delimitations of the PPAs were performed using ArcGIS 10.1 and the XToolPro 9.0 extension. A total of 5,003.82 hectares of Permanent Preservation Areas were delimited along the margins of the rivers analyzed, with a margin of error of $<1 \%$ in delimiting the widths of the rivers within the entire area considered. The methodology described here can be used to define PPAs efficiently, relatively rapidly, and with very small margins of error, thus representing a technological advance in terms of using GIS for land management.
\end{abstract}

Key-words: PPA; Mapping; Geographic Information Systems.

\section{MÉTODO PARA DELIMITAÇÃO AUTOMÁTICA DE ÁREAS DE PRESERVAÇÃO PERMANENTE AO LONGO DE RIOS - USO DE SIG NA BACIA DO RIO SERGIPE}

\begin{abstract}
RESUMO - As Áreas de Preservação Permanente (APPs) ao longo dos cursos d'água são foco de diversos estudos, não só por sua fragilidade e relevância ecológica, mas pelo ineficaz cumprimento das legislações que a protegem. Uma das maiores dificuldades de garantir a efetiva conservação dessas áreas é a ausência de metodologias que possam delimitá-las rapidamente ao longo de rios sem seccionar manualmente as larguras do rio ou realizar tal procedimento de forma apenas linear para todo o rio. O objetivo do trabalho foi desenvolver um método de análise espacial para delimitar automaticamente a área de preservação permanente ao longo de um curso d'água com a utilização de um Sistema de Informações Geográfica (SIG). O estudo foi realizado na bacia hidrográfica do rio Sergipe, rio que dá nome ao estado, tendo sido aplicada a metodologia aos seus principais rios e afluentes. Para o estudo foi utilizada a base de dados do Atlas Digital sobre Recursos Hídricos - SEMARH/SE, e a delimitação das APPs foi realizada por meio do ArcGIS 10.1 e da extensão XToolPro 9.0. Foi delimitado um total de 5.003,82 hectares de áreas de preservação permanente às margens dos rios analisados, com uma margem de erro inferior a $1 \%$ na delimitação da largura dos rios em toda a extensão
\end{abstract}


mapeada pela metodologia desenvolvida. O método apresentado realizou o procedimento de delimitação das APPs de forma eficiente, com uma margem pequena de erro, se tornando um avanço tecnológico no que diz respeito à aplicação de SIG para a gestão territorial.

Palavras-chave: APP; Mapeamento; Sistemas de Informações Geográficas.

\section{INTRODUCTION}

The establishment of protected natural areas has been the focus of governments and civil organizations throughout the world. According to the IUCN, protected areas are territorial spaces established by laws or other legally valid mechanisms designed to protect biodiversity and natural or cultural resources under public or civil management (SCHERL et al., 2006).

Brazilian environmental legislation has established numerous mechanisms for protecting the environment through the creation of legally protected areas. These protected areas can be territorial sites defined and delimited by the government for specific purposes, including Conservation Units (CU) (BRASIL, 2000), Legal Reserves (LR), and Permanent Preservation Areas (PPAs) (BRASIL, 2012).

Among these different categories, PPAs have gained special attention in terms of land management as they do not depend on additional administrative acts to be established (such as official government decrees in the case of CUs), or official registration (as in the case of LRs), but have well-defined and fundamental objectives, including the preservation of natural resources, environmental quality, and biodiversity, as well as guaranteeing the well-being of human populations (BRASIL, 2012).

According to Eugenio et al. (2011), mapping PPAs is a priority and strategic to their effective administration, and represents a primary subsidy for land management and monitoring. In spite of the obvious relevance of mapping these areas this step is rarely officially undertaken for number of reasons, including the lack of interest of the central government in including these areas in strategic plans (RIBEIRO et al., 2005), thus making this theme much more present in the academic literature than in administrative thinking (NOWATZKI et al., 2010; GONÇALVES et al., 2012; LEAL et al., 2013; CARDOSO; AQUINO, 2013).

Geoprocessing has been widely used for analyzing natural resources (SOARES et al., 2011) due to the ease and efficiency of computerized mapping (EUGENIO et al., 2011), assuring greater agility in generating, distributing, and implementing information.

In terms of PPAs, however, the delimitation of river margins has been particularly troublesome due to a generalized lack of detailed hydrographic maps, the heterogeneity of the dimensions of the rivers along their courses, and the lack of consolidated methodologies that would allow the rapid measurement and definition of legally protected areas with only small margins of error.

As such, the present work sought to develop a rapid and efficient methodology using Geographical Information Systems for automatically defining Permanent Preservation Areas along watercourses that conform to the requirements of Brazilian environmental legislation.

\section{MATERIALS AND METHODS}

\subsection{Characterization of the study area}

The study area selected was the hydrological basin

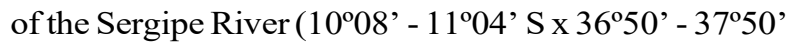
W). The methodology developed was applied to the principal rivers of that basin, including the Sergipe, do Sal, Cotinguiba, Cajaíba, Ganhamoroba, Cabuçu, Parnamirim, Pomonga, and Tiloto rivers, as well as some of their smaller affluents (Figure 1). The Poxim River is one of the largest in the region and makes up part of the hydrological basin examined. It was not included in the present study, however, as inconsistencies were detected in terms of the area of its polygon due to problems related to resolution that would result in significant errors in delimiting its PPAs.

The regional climate is tropical with a dry summer season (AS', according to the Koppen system) (EMBRAPA, 2009). Santos and Araújo (2013) described the region as under a predominantly sub-humid climate, with a large percentage of its area modified by human activities, principally agriculture and pasture, although with significant coverage of mangrove swamps along the margins of the principal rivers. 


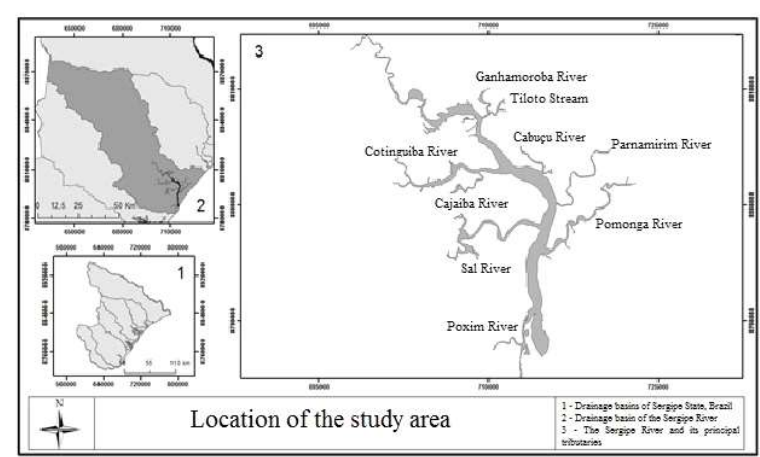

Figure 1 - Location of the study area.

Figura 1 - Localização da área de estudo.

\subsection{Delimitation of Permanent Preservation Areas along watercourses}

The application of the methodology described here requires that the rivers to be mapped must be represented as polygons. The use of polygons, preferentially derived from high-resolution images such as those from aerial photographic surveys, is most appropriate for our purposes as polygons provide sharp definitions of the edges of the features of interest. The use of raster data, principally data derived from low resolution sources, tends to compromise the definitions of object edges, principally due to the problem of pixel mixing.

The present work used the polygonal mapping of the Digital Atlas of Hydrological Resources produced by the Secretary of State for Environment and Hydric Resources (Secretaria de Estado do Meio Ambiente e dos Recursos Hídricos) - SEMARH (2012). The delimitation of the PPAs was performed using ArcGIS ${ }^{\circledR}$ 10.1 and the XToolPro ${ }^{\circledR} 9.0$ extension.

The river polygon was converted to polylines, resulting in a vectorial shape file corresponding to the river margins to be analyzed. The lines were then segmented, meter by meter, comprising a sampling set of 301,389 segments. The original polygon was also used to generate a raster file of the river that was used in the key procedure of this mapping - the vectorization of its central line.

These files were used to calculate the distances between the segments that compose the river margins and the central line of the river, using the near function that calculates the smallest distance between two features. As such, it was possible to calculate the exact

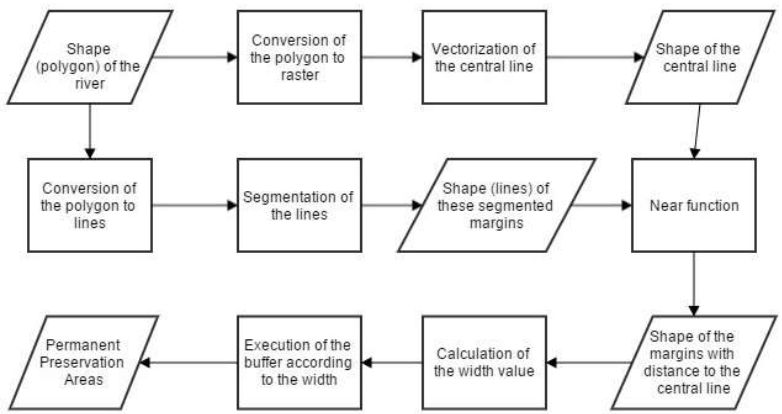

Figure 2 - Flow diagram of the methodology used. Figura 2-Fluxo do processo para execução desta metodologia.

width of the river to each $1 \mathrm{~m}$ segment along its margins. To calculate the absolute river width values, a new field was inserted in the table of segment attributes that doubled the results of the near function.

Having determined the river width data, the segments were transferred to separate files according to river width categories as determined by law (BRASIL, 2012): up to $10 \mathrm{~m}$; from 10 to $50 \mathrm{~m}$; from 50 to $200 \mathrm{~m}$; from 200 to $600 \mathrm{~m}$; and greater than $600 \mathrm{~m}$. A buffer was generated for each of these groups according to the corresponding legal PPA depths: $30 \mathrm{~m} ; 50 \mathrm{~m} ; 100 \mathrm{~m}$; $200 \mathrm{~m} ; 500 \mathrm{~m}$ respectively.

The dissolve function was used to generate a single shape from each group of buffer widths. The extremities of the segments were flattened using the flat option and, to avoid possible errors resulting from the overlapping of opposite margins, the buffers were projected to only one side of each segment.

The files containing the buffers were then unified and consolidated into a single shape file and the hydrological features subsequently erased, resulting in a single file that represented the PPA areas of the rivers within the hydrological basin.

\section{RESULTS}

A total of 5,003.82 hectares of Permanent Preservation Areas along the margins of the rivers of the Sergipe River water basin were mapped using this methodology (Figure 1). After visual reviews and corrections of the shapes, it was determined that this methodology generated delimitation errors of less than $1 \%$ in terms of the river widths in the mapping area.

Revista Árvore, Viçosa-MG, v.40, n.2, p.229-234, 2016

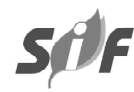


The technique presented here efficiently mapped the riverside PPAs, automatically accompanying variations in their widths throughout the river courses, as can be seen in Figure 4.

\section{DISCUSSION}

Errors encountered during the execution of the methodology described here were principally due to occasional fragility in the vectorization of the automatically generated central line of the river; these

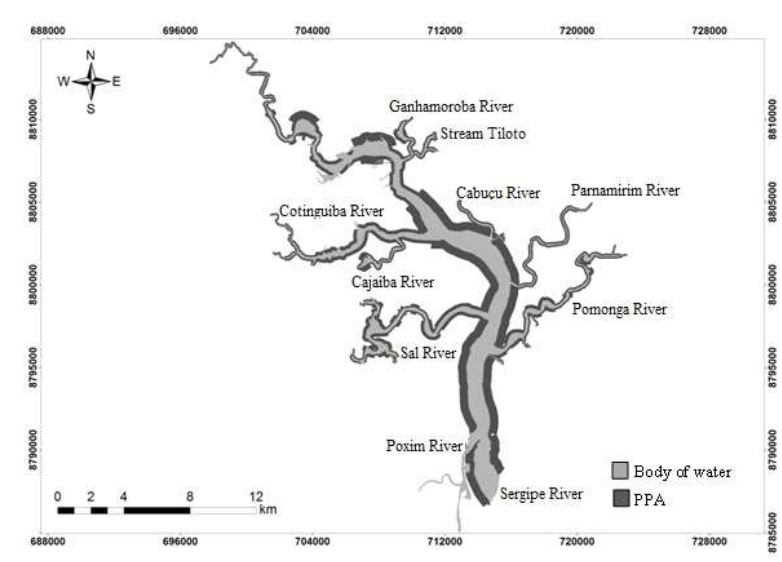

Figure 3 -Delimitation of PPA of the Sergipe River and its major tributaries as proposed by the methodology described here.

Figura 3 -Delimitação da APP para o rio Sergipe e seus principais afluentes pelo método proposto.

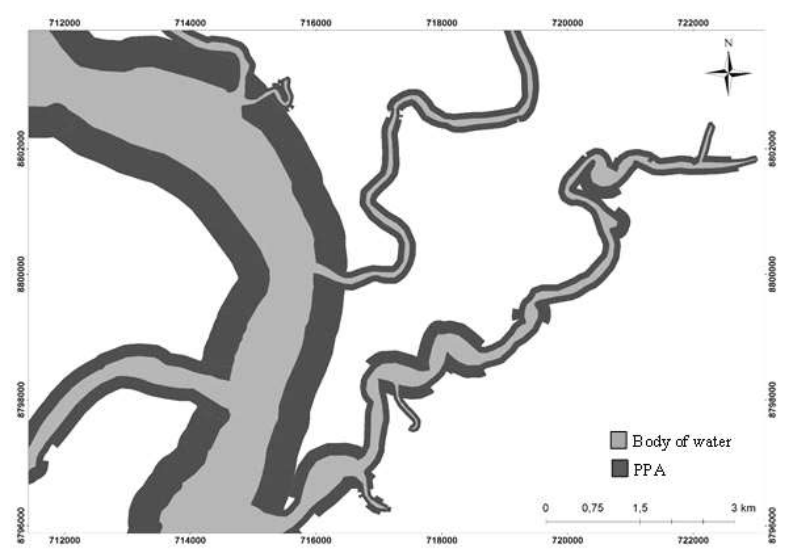

Figure 4 - Detail of a section of the river with areas of PPA as mapped using the proposed methodology.

Figura 4-Detalhe do trecho de rio com a APP mapeada através da metodologia proposta. errors were concentrated in areas with accentuated curves and in sections of the river showing sudden variations in their widths.

To increase the precision of the methodology adopted and reduce possible errors (river sections with accentuated curves and bifurcations), the polygon of the river, which was initially defined as a single feature, was divided into its principal course and affluents, thus allowing us to determine the sizes of the raster cells independently for rivers of different sizes.

This modification was necessary because the vectorization method utilized can recognize only a maximum of 100 cells representing the width of a raster and, to avoid this limitation, cell sizes must be determined in a manner compatible with the widths of the different sections of the rivers.

One of the principal advantages of this new methodology is that it requires only a polygonal layer representing the watercourses where the PPAs are to be created - and no other digital data - and can thus be easily and rapidly used to facilitate conformation with environmental legislation, with only small margins of error and requiring only the appropriate software, quality data, and professionals trained to execute this work.

Maps of water resources are predominantly prepared using lines that represent only the watercourse (not its true margins), which can generate significant errors in delimiting PPAs. The methodology proposed here provides for mapping water resources at high levels of detail, providing a more precise and reliable spatial analyses of both river margins, the results of which can be used for mapping, zoning, and/or planning.

Additionally, this methodology represents an important technological evolution as it allows the automatic delimitation of river courses, river margins, and PPAs - without the necessity of manually sectioning the river according to width categories to create buffer zones (or simply disconsider width variations and create uniform linear protection zones).

While GIS and other geotechnologies are exceedingly well-established as instruments for the analysis and modeling of geographic spaces and quite efficient in delimiting PPAs (GONÇALVES et al., 2012), it will always be necessary to further refine these 
techniques and systems in response to new technological and software developments and to streamline and expand their operationality while maintaining the reliability of the data generated.

As such, technological innovations in terms of equipment utilization, together with the development of sophisticated algorithms and their incorporation into established geo-technological functions, must be constant and continuous so that the data necessary for spatial characterizations can be processed more rapidly and efficiently (OLIVEIRA, 2002)

The evolution of geoprocessing as seen in the increasing improvements of the methods and tools used in GIS geotechnologies in general, together with increasing capacities for data processing have made it progressively easier to overcome difficulties in the execution of geo-environmental studies (BATISTELLA; BOLFE, 2012).

\section{CONCLUSIONS}

The methodology presented here represents an advance in the application of GIS in land management questions, providing a practical, low cost, and relatively simple manner of mapping PPA along river margins with high reliability. It is hoped that this type of mapping can be used, especially by local municipal governments, for planning and monitoring of the lands and natural resources under their jurisdiction.

It is of fundamental importance to incorporate the results of studies such as this into administrative processes that oversee the use and occupation of both public and private lands in order to guarantee the effective application of the pertinent legislation and assure adherence to its primary objectives. The development of new technologies and software, and the training of professionals to work with these new activities, will be indispensable for environmental planning and monitoring at all levels.

The generation of data such as that presented here is, of course, only the first step, and must be followed by the structuring of public institutions to absorb this information and integrate it into routine institutional processes so that methodologies such as those described here can be used to generate useful information that results in concrete actions for the effective conservation of the natural environment.

\section{REFERENCES}

BRASIL. Lei $\mathbf{n}^{\mathbf{9}} \mathbf{9 . 9 8 5}$, de 18 de Julho de 2000 . Institui o Sistema Nacional de Unidades de Conservação da Natureza e dá outras providências. Brasília, 2000. Disponível em: http:// www.planalto.gov.br/ccivil_03/leis/19985.htm. Acesso em: 15 jan. 2014.

BRASIL. Lei no 12.651, de 25 de Maio de 2012. Dispõe sobre a proteção da vegetação nativa. Brasília, 2012. Disponível em: http:// www.planalto.gov.br/ccivil_03/_ato2011-2014/2012/ lei/112651.htm. Acesso em: 15 jan. 2014.

BATISTELLA, M.; BOLFE, E.L. Pesquisa, desenvolvimento e inovações geoespaciais para a agropecuária. Revista Pesquisa Agropecuária Brasileira, v.47, n.9, p.iii-vii, 2012.

CARDOSO, J.A.; AQUINO, C.M.S. Mapeamento dos conflitos de uso nas áreas de preservação permanente (APPs) da microbacia do riacho do Roncador, Timon (MA). Boletim Goiano de Geografia, v.33, n.3, p.477-492, 2013.

EMPRESA BRASILEIRA DE PESQUISA AGROPECUÁRIA - EMBRAPA. Regionalização de precipitações médias e prováveis mensais e anuais no Estado de Sergipe. Boletim de Pesquisa e Desenvolvimento, n.54, 2009. Disponível em: http://www.cpatc.embrapa.br/publicacoes_2009/ bp_54.pdf. Acesso em: 25 jan. 2014.

EUGENIO, F. C.; SANTOS, A. R.; LOUZADA, F. L. R.O.; PIMENTEL, L. B.; MOULIN, J. V.

Identificação das Áreas de Preservação Permanente no Município de Alegre Utilizando Geotecnologia. CERNE, v.17, n.4, p.563-571, 2011.

GONÇALVES, A. B.; MARCATTI, G. E.; RIBEIRO, C. A. A. S.; SOARES, V. P.; NETO, M.; ALVES, J. A.; LEITE, H. G.; GLERIANI, J. M.; LANA, V. M. Mapeamento das áreas de preservação permanente e identificação dos conflitos de uso da terra na sub-bacia hidrográfica do rio Camapuã/Brumado. Revista Árvore, v.36, n.4, p.759-766, 2012.

LEAL, J.V.; TODT, V.; THUM, A.B. O uso de SIG para monitoramento de áreas degradadas estudo de caso: APP do Arroio Gil, Triunfo-RS. Revista Brasileira de Cartografia, v.65, n.5, p.967-983, 2013.

Revista Árvore, Viçosa-MG, v.40, n.2, p.229-234, 2016 
NOWATZKI, A.; SANTOS, L.J.C.; PAULA, E.V. Utilização do SIG na delimitação das áreas de preservação permanente (APP's) na bacia do rio Sagrado (Morretes/PR). Revista Sociedade \& Natureza, v.22, n.1, p.107-120, 2010.

OLIVEIRA, M.J. Proposta metodológica para delimitação automática de áreas de preservação permanente em topo de morro e em linha de cumeada. 2002. 53f. Dissertação (Mestrado em Ciência Florestal) - Universidade Federal de Viçosa, Viçosa-MG, 2002.

RIBEIRO, C. A. A. S.; SOARES, V. P.; OLIVEIRA, A. M. S.; GLERIANI, J. M. O desafio da delimitação de áreas de preservação permanente. Revista Árvore, v.29, n.2, p.203-212, 2005.

SANTOS. W.A.; ARAÚJO, H.M. Clima e condições meteorológicas da sub-bacia hidrográfica do rio Cotinguiba-SE. Boletim da Geografia, v.31, n.1, p.41-52, 2013.

SCHERL, L. M.; WILSON, A.; WILD, R.; BLOCKHUS, J.; FRANKS, P.; MCNEELY, J. A.; MCSHANE, T. O. As áreas protegidas podem contribuir para a redução da pobreza? Oportunidades e limitações. Londres: IUCN, 2006. 60 p.

SERGIPE. Atlas digital sobre recursos hídricos de Sergipe. Sistema de informações sobre recursos hídricos de Sergipe SRHSE, versão 2012.9 .

SOARES, V. P.; MOREIRA, A.A.; RIBEIRO, C. A. A.S.; GLERIANI, J. M. Mapeamento das áreas de preservação permanente e dos fragmentos florestais naturais como subsidio à averbação de reserva legal em imóveis rurais. CERNE, v.17, n.4, p.555-561, 2011. 